\title{
Karotinoid- és peptidmintázatok elemzése mikroalgákból
}

Vasas Gábor ${ }^{1, *}$, Deli József², Riba Milán ${ }^{1}$, Ujvárosi Andrea $^{1}$, Hanyicska Martin ${ }^{1}$, Gonda Sándor ${ }^{1}$, Kapás Kitti ${ }^{1}$

${ }^{1}$ DE Növénytani Tanszék, 4032 Debrecen, Egyetem tér 1.

2 PTE GYTK Farmakognóziai Intézet, 7624 Pécs, Rókus u 2.

*e-mail: vasas.gabor@science.unideb.hu

A gyógyászatban felhasznált, étrend-kiegészítőként alkalmazott növényi eredetú készítmények, gyógyszerek manapság még több mint 90 \%-a a magasabb szerveződésű hajtásos növényekből származnak, ugyanakkor egyre nagyobb figyelem irányul a mikroalgák ilyen irányú alkalmazására. Részben tradicionális okokból, részben napjaink klinikai, preklinikai vizsgálataira alapozva néhány algafaj terméke közvetlen felhasználásra kerül étrend-kiegészítőként, gyógyhatású készítményként. Az elmúlt időszakban, párhuzamosan a szerkezetazonosító módszerek fejlődésével, ezen élőlénycsoportból számos különleges metabolit, különböző biológiai aktivitással került leírásra.

A növényvilág talán legszembetűnőbb, szemet gyönyörködtetőbb molekulái azok a karotinoid színanyagok amelyek, részben fotoszintézisük hatékonysága érdekében, részben védekezés vagy egyéb funkciók érdekében termelnek a növények, így az algák is. Egyes mikroalgák, cianobaktériumok pedig lineáris és ciklikus peptidtermelése jelentős aktivitást mutat, amelyek közül elsősorban egyes proteázgátlók számítanak jelentős érdeklődésre.

Előadásunkban, a kutatócsoportunk elmúlt éveinek alapkutatási eredményeit foglaljuk össze e témakörben, amelyben a karotinoidok és az erős biológiai aktivitással bíró peptidek, glikopeptidek azonosítását, sajátosságainak elemzését végeztük mikroalgákból. Előadásunkban tárgyaljuk:

- A Dunaliella sp. mikroalga karotinoidtermelésének sajátosságait

- A Haematococcus pluvialis astaxantin termelésének és azonosításának eredményeit

- Egy vízoldékony karotinoid-glikozid azonosítását mikroalgából

- Peptidmintázatok elemzését és biológiai aktivitását cianobaktériumokból 